\title{
CHARACTERISTIC EQUATIONS OF VACUUM AND GAS- FILLED TUNGSTEN-FILAMENT LAMPS
}

\author{
By L. E. Barbrow and J. Franklin Meyer
}

ABSTRACT

The manufacture of tungsten-filament incandescent lamps has changed very rapidly during recent years, and methods of lamp photometry have necessarily changed with the changes in the lamps. Photometric measurements have passed very largely from a mean horizontal candlepower basis to a lumen basis. The tables of characteristic relations of vacuum lamps, published in 1914 and based on measurements of horizontal candlepower, are no longer adequate for the newer types and larger sizes of lamps.

Logarithmic equations of the second degree are shown to apply to vacuum lamps and to gas-filled lamps in three steps. The equations describe the characteristics of miniature lamps as well as large lamps. Tables of characteristic relations, based on normal efficiencies of 10.0, 12.5, and 16.0 lumens per watt, computed by means of the characteristic equations, furnish means for ready calculation of light output, current, power input, and operating efficiency over a range of voltages from 55 per cent of normal voltage for vacuum lamps, and 80 per cent of normal voltage for gas-filled lamps, to 120 per cent of normal voltage for all types and sizes up to 150 watts, and to 132 per cent of normal voltage for large gas-filled lamps, sizes 200 watts and up.

\section{CONTENTS}

I. Introduction

II. The lumen basis of incandescent lamp measurement 1. Changes in lamp construction

2. Photometry of vacuum and gas-filled lamps.

III. The characteristic equations of incandescent lamps........... IV. Tables of characteristic relations of vacuum and gas-filled tungsten

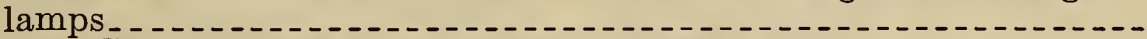

1. Characteristics of vacuum tungsten lamps

2. Method of using the tables of characteristic relations....-

3. Characteristics of gas-filled tungsten lamps.......

V. Verification of the characteristics

VI. Conclusion and acknowledgments

\section{INTRODUCTION}

In a previous Bureau of Standards publication ${ }^{1}$ the derivation of characteristic equations of the form

$$
y_{n}=A_{n} x^{2}+B_{n} x+C
$$

from data obtained on vacuum tungsten lamps was fully described and applications of the equations to problems of the lamp standardizing and testing laboratory were illustrated. The equations were shown to express the relations of voltage to candlepower, to current, to watts input, and to the "efficiency," expressed in terms of watts per candle, over the range from 3.3 to 0.7 watts per candle. In these equations the variable $x$ is the logarithm of the ratio of any voltage to that voltage at which a lamp operates when it emits light at an assumed

1 Middlekauff and Skogland, Characteristic Equations of Tungsten Filament Lamps, B. S. Sci. Paper No. 238. Bull. B. S., จol. 11, p. 483, 1915. 
"normal" efficiency. The variable $y_{n}$ is the logarithm of the ratios of currents, candlepowers, or watts at these voltages, or the logarithm of "efficiency," expressed in watts per candle, at any voltage. $A$, $B$, and $C$ are constants. Tables of the characteristic relations were included in the original paper. These have proved very useful in lamp testing and standardization, but need to be revised and extended in order to be applicable to lamps manufactured now. The necessary revisions and extensions are included in this paper.

\section{THE LUMEN BASIS OF INCANDESCENT LAMP MEASUREMENT}

\section{CHANGES IN LAMP CONSTRUCTION}

The earlier paper was published before the integrating sphere photometer had come into general use for measuring the total light output of lamps. Practically all lamps then had "squirrel-cage" filaments in clear bulbs and were rated by the manufacturers at socalled efficiencies expressed as watts per mean horizontal candle. Photometric measurements made on a horizontal bar photometer were therefore all that were required for the rating of lamps.

Within the last few years bulb sizes, shapes, and finishes have been changed, as have also the methods of mounting and supporting the filament. Inside-frosted, diffusing bulbs are used now on all sizes of lamps from 15 to 100 watts, and on many of the larger sizes of lamps. The ring-wound, coiled filament has replaced the "squirrel-cage" type of filament mounting. Besides, practically all lamps of 40 watts and above are now gas-filled instead of vacuum. These changes in the construction of lamps have caused changes in their characteristics which have been taken into account in the equations and tables of this paper.

\section{PHOTOMETRY OF VACUUIM AND GAS-FILLED LAMPS}

It has long been known that horizontal candlepower measurements on gas-filled lamps present great difficulties and are generally unreliable. ${ }^{2}$ Besides, for most illuminating engineering purposes a knowledge of the total light output of lamps rather than the candlepower in a particular direction is desired. Horizontal candlepower measurements on all types of lamps therefore have been given up almost entirely in commercial and testing-laboratory practice, and measurements of spherical candlepower or total flux have taken their place. In this paper the watts-per-candle basis of the characteristic equations given in Scientific Paper No. 238 has been replaced by a lumen-perwatt basis.

To make the equations of Scientific Paper No. 238 applicable to vacuum lamps when measured in lumens, conversion of mean horizontal candlepower values to lumen values is necessary. The spherical reduction factor, that is, the ratio of mean spherical candlepower to mean horizontal candlepower, for vacuum tungsten lamps, with "squirrel-cage" filament mountings, such as were used in 1914, is approximately 0.78 . The normal basis for photometric measurements of vacuum tungsten lamps was formerly generally accepted as 1.20

Middlekauff and Skogland, Photometry of Gas-Filled Lamps, Elec. World, Dec. 26, 1914, p. 1248; and B. S. Sci. Paper No. 264. Bull. B. S., vol. 12, p. 589, 1915-16. C. H. Sharp, Trans. Ill. Eng. Soc., vol. 9, p. $1021,1914$. 
watts per mean horizontal candle. This normal value of 1.20 watts per candle becomes 8.17 lumens per watt $\left(\frac{0.78 \times 4 \pi}{1.20}=8.17\right)$ when the lamps are measured on a lumen basis. This is a much lower efficiency than that at which most vacuum tungsten lamps are now made, and consequently a value of 10.0 lumens per watt has been arbitrarily chosen, on which basis tabular values for vacuum tungsten lamps are calculated in this paper. The characteristics of clear vacuum tungsten lamps as derived in 1914 have been found to apply also to the insidefrosted vacuum lamps as made to-day, so that the equations and tables in this paper for vacuum lamps are fundamentally the same as those contained in Scientific Paper No. 238, but are modified from the candle to the lumen basis and the normal efficiency is increased from 8.17 to 10.0 lumens per watt. The equations for gas-filled lamps have different constants, but are of the same form as the equations for vacuum lamps.

The data from which were derived the equations for gas-filled lamps of sizes ranging from 200 watts up are the result of a very large number of measurements made over a period of 10 years at the Bureau of Standards and at the laboratories of manufacturers of incandescent lamps. The normal efficiency chosen for these equations is 16.0 lumens per watt. It has been found, however, that these equations do not fit the characteristics of the smaller sizes of gas-filled lamps. Two other sets of equations, one for gas-filled lamps of sizes 60 to 150 watts, and the other for gas-filled lamps of 40 and 50 watts have been derived. Both of these sets of equations are on a normal basis of 12.5 lumens per watt. It has been found, also, that the 200 to 500 watt equations and 60 to 150 watt equations describe the characteristics of 32 and 21 candlepower automobile headlamps, respectively, while the 40 to 50 watt equations are suitable for 3 candlepower, 6 to 8 volt lamps.

\section{THE CHARACTERISTIC EQUATIONS OF INCANDES- CENT LAMPS}

The logarithmic form of characteristic equation as applied to vacuum lamps is completely discussed by Middlekauff and Skogland in their original paper, ${ }^{3}$ page 494 and following. The form of equation for vacuum lamps:

$$
y_{n}=A_{n} x^{2}+B_{n} x+C \quad(n=1,2,3,4)
$$

is found to apply to gas-filled lamps also. In this equation the independent variable $x$ refers to voltage, and $y_{n}$ and the corresponding constants $A_{n}, B_{n}$, and $C$ to the efficiency in lumens per watt $(n=1)$, light putput $(n=2)$, power $(n=3)$, and current $(n=4)$. There are then four problems to which the general equation is applicable. The rariable $x$ is the logarithm of the voltage ratio in each case; that is

and

$$
x=\log \text { (voltage ratio) }
$$

$$
\begin{aligned}
& y_{1}=\log \text { (lumens per watt) } \\
& y_{2}=\log \text { (light output ratio) } \\
& y_{3}=\log \text { (power ratio) } \\
& y_{4}=\log \text { (current ratio) }
\end{aligned}
$$

See footnote 1, 
Constants $A_{n}, B_{n}$, and $C$ have been computed on the selected normal bases of $10,12.5,12.5$, and 16 lumens per watt, respectively, for vacuum lamps and for the three groups of different sizes of gas-filled lamps. These constants for the vacuum-lamp equations were derived from the constants contained in Bureau of Standards Scientific Paper No. 238, as previously indicated. For the various sizes of gas-filled lamps they were determined by setting up logarithmic curves of the relations, voltage ratio to luminous flux ratio, and voltage ratio to efficiency, using data obtained on several sizes of lamps measured over a wide range of voltages. The coefficients $B_{1}$ and $B_{2}$ were then determined as the slopes of these curves at the normal efficiency. The coefficients $A_{1}$ and $A_{2}$ were determined from the rates of change of these slopes. Coefficient $C$ is the logarithm of the normal efficiency. Coefficients $A_{3}, A_{4}, B_{3}$ and $B_{4}$ are not independent of the above coefficients, $A_{3}$ and $A_{4}$ being equal to $\left(A_{2}-A_{1}\right), B_{3}$ being equal to $\left(B_{2}-B_{1}\right)$, and $B_{4}$ being equal to $\left(B_{3}-1\right)$.

General equation:

TABLE 1.-Constants in the characteristic equations

$y_{n}=A_{n} x^{2}+B_{n} x+C$

in which $x$ is $\log$ (voltage ratio), and $y_{n}$ is the logarithm of the quantity given in the right-hand column of this table.

CONSTANTS

\begin{tabular}{|c|c|c|c|c|c|}
\hline & Vacuum & \multicolumn{3}{|c|}{ Gas-filled lamps } & \multirow[b]{6}{*}{$\begin{array}{l}\text { Lumens per watt. } \\
\text { Do. } \\
\text { Do. } \\
\text { Light output (lumens) ratio. } \\
\text { Do. } \\
\text { Power (watts) ratio. } \\
\text { Do. } \\
\text { Current (amperes) ratio. } \\
\text { Do. }\end{array}$} \\
\hline & \multicolumn{4}{|c|}{ Size } & \\
\hline & $15-60 \mathrm{w}$ & $40-50 \mathrm{w}$ & $60-150 \mathrm{w}$ & $200-500 \mathrm{w}$ & \\
\hline & \multicolumn{4}{|c|}{ Normal lumens per watt } & \\
\hline & 10.0 & 12.5 & 12.5 & 16.0 & \\
\hline 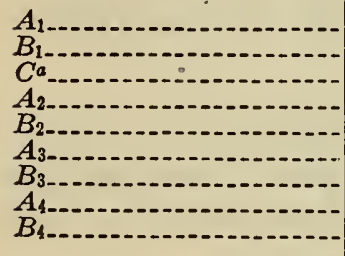 & $\begin{array}{l}-0.918 \\
1.932 \\
1.00000 \\
-.946 \\
3.513 \\
-.028 \\
1.5805 \\
-.028 \\
.5805\end{array}$ & $\begin{array}{l}-1.482 \\
2.162 \\
1.09691 \\
-1.425 \\
3.685 \\
.057 \\
1.523 \\
.057 \\
.523\end{array}$ & $\begin{aligned}-1.726 \\
2.090 \\
1.09691 \\
-1.669 \\
3.613 \\
.057 \\
1.523 \\
.057 \\
.523\end{aligned}$ & $\begin{array}{c}-1.690 \\
1.841 \\
1.20412 \\
-1.607 \\
3.384 \\
.083 \\
1.543 \\
.083 \\
.543\end{array}$ & \\
\hline
\end{tabular}

a $\mathrm{C}=0$ for the other relations.

Example.-The lumens-per-watt equation for 500-watt, gas-filled lamps, with normal (100 per cent) value at 16.0 lumens per watt, is

$$
y_{1}=-1.690 x^{2}+1.841 x+1.20412
$$

where $x$ is the logarithm of the ratio of any desired voltage to the voltage at normal efficiency (16.0 lumens per watt) and $y_{1}$ is the logarithm of the efficiency of the lamps at the desired voltage.

It is of interest to note that the coefficient of $x\left(B_{1}, B_{2}, B_{3}\right.$, or $\left.B_{4}\right)$ in each case in Table 1 is very closely the exponent of the relationship existing between voltage and any one of the dependent variables listed in the last column of the table. For example, the efficiency of 500 -watt lamps varies as the 1.84 power of the voltage; the luminous flux varies as the 3.38 power of the voltage; and the current varies as the 0.54 power of the voltage. These exponents are strictly applicable only for small changes of voltage near normal efficiency, but can be used through a wider range of voltages where only fairly close approximations are required.

There are 16 characteristic equations that can be written by using the constants of Table 1 to cover the four groups of lamp sizes, and the 
four dependent characteristic variables of each group. It is not convenient, however, to use these equations directly in computations, because one usually does not know the voltage at which a particular lamp is to be operated to give the normal efficiency, and this must be determined before the equations can be used to give the value of any of the dependent variables at any desired voltage. To facilitate computations, Tables $2,3,4$, and 5 , which follow, have been set up by using the 16 characteristic equations, and their use is discussed below.

\section{TABLES OF CHARACTERISTIC RELATIONS OF VACUUM AND GAS-FILLED TUNGSTEN LAMPS}

\section{CHARACTERISTICS OF VACUUM TUNGSTEN LAMPS}

TABLE 2.-Characteristics of vacuum tungsten lamps, 15 to 60 watts (normal efficiency, 10 lumens per watt)

$\begin{array}{ll}y_{1}=-0.918 x^{2}+1.932 x+1.000 & \text { (used to obtain column 2) } \\ y_{2}=-0.946 x^{2}+3.513 x & \text { (used to obtain column 3) } \\ y_{4}=-0.028 x^{2}+0.5805 x & \text { (used to obtain column 4) } \\ y_{3}=-0.028 x^{2}+1.5805 x & \text { (used to obtain column 5) }\end{array}$

\begin{tabular}{|c|c|c|c|c|c|c|c|c|c|}
\hline $\begin{array}{c}\text { Percent- } \\
\text { age of } \\
\text { normal } \\
\text { volts }\end{array}$ & $\begin{array}{c}\text { Lumens } \\
\text { per } \\
\text { watt }\end{array}$ & $\begin{array}{l}\text { Percent- } \\
\text { age of } \\
\text { normal } \\
\text { lumens }\end{array}$ & $\begin{array}{c}\text { Percent- } \\
\text { age of } \\
\text { normal } \\
\text { amperes }\end{array}$ & $\begin{array}{c}\text { Percent- } \\
\text { age of } \\
\text { normal } \\
\text { watts }\end{array}$ & $\begin{array}{c}\text { Percent- } \\
\text { age of } \\
\text { normal } \\
\text { volts }\end{array}$ & $\begin{array}{c}\text { Lumens } \\
\text { per } \\
\text { watt }\end{array}$ & $\begin{array}{c}\text { Percent- } \\
\text { age of } \\
\text { normal } \\
\text { lumens }\end{array}$ & $\begin{array}{l}\text { Percent- } \\
\text { age of } \\
\text { normal } \\
\text { amperes }\end{array}$ & $\begin{array}{c}\text { Percent- } \\
\text { age of } \\
\text { normal } \\
\text { watts }\end{array}$ \\
\hline 1 & 2 & 3 & 4 & 5 & 1 & 2 & 3 & 4 & 5 \\
\hline $\begin{array}{l}55 \\
56 \\
57 \\
58 \\
59\end{array}$ & $\begin{array}{l}2.74 \\
2.85 \\
2.97 \\
3.10 \\
3.23\end{array}$ & $\begin{array}{l}10.6 \\
11.4 \\
12.2 \\
13.1 \\
14.0\end{array}$ & $\begin{array}{l}70.4 \\
71.1 \\
71.9 \\
72.6 \\
73.4\end{array}$ & $\begin{array}{l}38.7 \\
39.8 \\
41.0 \\
42.1 \\
43.3\end{array}$ & $\begin{array}{l}90 \\
91 \\
92 \\
93 \\
94\end{array}$ & $\begin{array}{l}8.12 \\
8.30 \\
8.49 \\
8.67 \\
8.86\end{array}$ & $\begin{array}{l}68.7 \\
71.5 \\
74.4 \\
77.3 \\
80.3\end{array}$ & $\begin{array}{l}94.1 \\
94.7 \\
95.3 \\
95.9 \\
96.5\end{array}$ & $\begin{array}{l}84.6 \\
86.1 \\
87.6 \\
89.2 \\
90.7\end{array}$ \\
\hline $\begin{array}{l}60 \\
61 \\
62 \\
63 \\
64\end{array}$ & $\begin{array}{l}3.36 \\
3.49 \\
3.62 \\
3.76 \\
3.90\end{array}$ & $\begin{array}{l}14.9 \\
15.9 \\
17.0 \\
18.1 \\
19.2\end{array}$ & $\begin{array}{l}74.1 \\
74.8 \\
75.5 \\
76.3 \\
77.0\end{array}$ & $\begin{array}{l}44.4 \\
45.6 \\
46.8 \\
48.0 \\
49.3\end{array}$ & $\begin{array}{l}95 \\
96 \\
97 \\
98 \\
99\end{array}$ & $\begin{array}{l}9.05 \\
9.23 \\
9.42 \\
9.61 \\
9.80\end{array}$ & $\begin{array}{l}83.4 \\
86.6 \\
89.8 \\
93.1 \\
96.5\end{array}$ & $\begin{array}{l}97.1 \\
97.7 \\
98.3 \\
98.8 \\
99.4\end{array}$ & $\begin{array}{l}92.2 \\
93.7 \\
95.3 \\
96.8 \\
98.4\end{array}$ \\
\hline $\begin{array}{l}65 \\
66 \\
67 \\
68 \\
69\end{array}$ & $\begin{array}{l}4.04 \\
4.18 \\
4.33 \\
4.47 \\
4.62\end{array}$ & $\begin{array}{l}20.4 \\
21.6 \\
22.9 \\
24.3 \\
25.7\end{array}$ & $\begin{array}{l}77.7 \\
78.4 \\
79.1 \\
79.8 \\
80.5\end{array}$ & $\begin{array}{l}50.5 \\
51.7 \\
53.0 \\
54.3 \\
55.5\end{array}$ & $\begin{array}{l}100 \\
101 \\
102 \\
103 \\
104\end{array}$ & $\begin{array}{l}10.00 \\
10.19 \\
10.39 \\
10.58 \\
10.78\end{array}$ & $\begin{array}{l}100.0 \\
103.5 \\
107.2 \\
111.0 \\
114.8\end{array}$ & $\begin{array}{l}100.0 \\
100.6 \\
101.2 \\
101.7 \\
102.3\end{array}$ & $\begin{array}{l}100.0 \\
101.6 \\
103.2 \\
104.8 \\
106.4\end{array}$ \\
\hline $\begin{array}{l}70 \\
71 \\
72 \\
73 \\
74\end{array}$ & $\begin{array}{l}4.77 \\
4.92 \\
5.08 \\
5.23 \\
5.39\end{array}$ & $\begin{array}{l}27.1 \\
28.6 \\
30.2 \\
31.8 \\
33.5\end{array}$ & $\begin{array}{l}81.2 \\
81.8 \\
82.5 \\
83.2 \\
83.9\end{array}$ & $\begin{array}{l}56.8 \\
58.1 \\
59.4 \\
60.7 \\
62.1\end{array}$ & $\begin{array}{l}105 \\
106 \\
107 \\
108\end{array}$ & $\begin{array}{l}10.98 \\
11.18 \\
11.38 \\
11.58\end{array}$ & $\begin{array}{l}118.6 \\
122.5 \\
126.5 \\
130.6\end{array}$ & $\begin{array}{l}102.9 \\
103.4 \\
104.0 \\
104.6\end{array}$ & $\begin{array}{l}108.0 \\
109.6 \\
111.3 \\
112.9\end{array}$ \\
\hline $\begin{array}{l}75 \\
76 \\
77 \\
78\end{array}$ & $\begin{array}{l}5.55 \\
5.71 \\
5.87 \\
6.04\end{array}$ & $\begin{array}{l}35.2 \\
37.0 \\
38.8 \\
40.7\end{array}$ & $\begin{array}{l}84.5 \\
85.2 \\
85.9 \\
86.5\end{array}$ & $\begin{array}{l}63.4 \\
64.7 \\
66.1 \\
67.5\end{array}$ & $\begin{array}{l}109 \\
110 \\
111 \\
112\end{array}$ & $\begin{array}{l}11.78 \\
11.98 \\
12.18 \\
12.38\end{array}$ & $\begin{array}{l}134.8 \\
139.2 \\
143.6 \\
148.1\end{array}$ & $\begin{array}{l}105.1 \\
105.7 \\
106.2 \\
106.8\end{array}$ & $\begin{array}{l}114.6 \\
116.3 \\
117.9 \\
119.6\end{array}$ \\
\hline 79 & 00 & 7 & & 60 & $\begin{array}{l}113 \\
114\end{array}$ & $\begin{array}{l}12.59 \\
12.79\end{array}$ & $\begin{array}{l}152.7 \\
157.4\end{array}$ & $\begin{array}{l}107.3 \\
107.9\end{array}$ & $\begin{array}{l}121.3 \\
123.0\end{array}$ \\
\hline $\begin{array}{l}80 \\
81 \\
82\end{array}$ & $\begin{array}{l}6.37 \\
6.54 \\
6.71\end{array}$ & $\begin{array}{l}44.7 \\
46.8 \\
49.0\end{array}$ & $\begin{array}{l}87.8 \\
88.4 \\
89.1\end{array}$ & $\begin{array}{l}70.2 \\
71.6 \\
73.0\end{array}$ & $\begin{array}{l}115 \\
116\end{array}$ & $\begin{array}{l}13.00 \\
13.21\end{array}$ & $\begin{array}{l}162.1 \\
166.9\end{array}$ & $\begin{array}{l}108.4 \\
109.0\end{array}$ & $\begin{array}{l}124.7 \\
126.4\end{array}$ \\
\hline $\begin{array}{l}83 \\
84\end{array}$ & $\begin{array}{l}6.88 \\
7.05\end{array}$ & $\begin{array}{l}51.2 \\
53.5\end{array}$ & $\begin{array}{l}89.7 \\
90.3\end{array}$ & $\begin{array}{l}74.5 \\
75.9\end{array}$ & $\begin{array}{l}117 \\
118 \\
119\end{array}$ & $\begin{array}{l}13.41 \\
13.62 \\
13.83\end{array}$ & $\begin{array}{l}171.8 \\
176.8 \\
181.9\end{array}$ & $\begin{array}{l}109.5 \\
110.0 \\
110.6\end{array}$ & $\begin{array}{l}128.1 \\
129.9 \\
131.6\end{array}$ \\
\hline $\begin{array}{l}85 \\
86 \\
87 \\
88 \\
89\end{array}$ & $\begin{array}{l}7.23 \\
7.40 \\
7.58 \\
7.76 \\
7.94\end{array}$ & $\begin{array}{l}55.9 \\
58.3 \\
60.8 \\
63.4 \\
66.0\end{array}$ & $\begin{array}{l}91.0 \\
91.6 \\
92.2 \\
92.8 \\
93.4\end{array}$ & $\begin{array}{l}77.3 \\
78.8 \\
80.2 \\
81.7 \\
83.1\end{array}$ & 120 & 14.04 & 187.2 & 111.1 & 133.3 \\
\hline
\end{tabular}

$145879-32-2$ 


\section{METHOD OF USING THE TABLES OF CHARACTERISTIC RELATIONS}

The method of using these tables is as follows:

1. It is assumed that a lamp has been photometered and that at a given voltage $V_{0}$, the current $A_{0}$, and lumen output $L_{0}$ have been directly measured, and from these values, the watts, $W_{0}$, and lumens per watt, $l_{\delta}$ have been computed. It is required to find the current, $A_{1}$, lumens $L_{1}$, watts $W_{1}$, and lumens per watt, $l_{1}$, at the required voltage $V_{1}$.

2. The tables must be entered at the value of lumens per watt, $l_{0}$, or if $l_{0}$ is not a tabulated value, then at the value of $l_{0}$ interpolated into the table.

3. In the line of the table in which $l_{0}$ is found or interpolated (column 2 of each table) read or interpolate $V_{t}, A_{t}, L_{t}$, and $W_{t}$, which are the percentages of normal volts, amperes, lumens, and watts, respectively, for the lamp when operated at $l_{0}$ lumens per watt. Thus $V_{0}$ is $V_{t}$ per cent of normal volts, $A_{0}$ is $A_{t}$ per cent of normal amperes, $L_{0}$ is $L_{t}$ per cent of normal lumens and $W_{0}$ is $W_{t}$ per cent of normal watts.

4. The voltage $V_{1}$ at which it is required to determine the current, watts, lumens, and lumens per watt of the lamp is then $\left(V_{1} / V_{0}\right) \times V_{t}$ per cent of normal volts; that is, letting $V^{\prime}{ }_{t}$ be the per cent of normal volts of the lamp at $V_{1}$ volts :

$$
V^{\prime}{ }_{i}=\left(V_{1} / V_{0}\right) \times V_{t}
$$

In the line of the table containing $V^{\prime}{ }_{t}$ or in an interpolated line, read or interpolate $l^{\prime}{ }_{t}, L^{\prime}{ }_{t}, A^{\prime}{ }_{t}$ and $W^{\prime}{ }_{t}$, the lumens per watt, per cent of normal lumens, per cent of normal amperes, and per cent of normal watts, respectively, of the lamp when operated at $V_{1}$ volts.

Then

$$
\begin{aligned}
l_{1}=l^{\prime}{ }_{t} & =\text { lumens per watt at } V_{1} \text { volts } \\
L_{1}=L_{0}\left(L^{\prime}{ }_{t} / L_{t}\right) & =\text { lumens at } V_{1} \text { volts } \\
A_{1}=A_{0}\left(A^{\prime}{ }_{t} / A_{t}\right) & =\text { amperes at } V_{1} \text { volts } \\
W_{1}=W_{0}\left(W^{\prime}{ }_{t} / W_{t}\right) & =\text { watts at } V_{1} \text { volts }
\end{aligned}
$$

also

$$
W_{1}=V_{1} A_{1}
$$

(a) NUMERICAL EXAMPLES ILLUSTRATING THE USE OF TABLES 2 TO 5

Example 1.-Given a vacuum tungsten lamp, which when burned at 115 volts, emits 243 lumens, and takes a current of 0.220 amperes. This lamp will hereafter in this example be referred to as the test lamp.

To find the lumen output, lumens per watt, current and power input of the test lamp at 124 volts.

Solution.-Find first by direct computation the watts and lumens per watt as follows:

Watts $=115 \times 0.220=25.3$.

Lumens per watt $=243 \div 25.3=9.61$.

The known values of the lamp are then:

$V_{0}=115$ volts.

$A_{0}=0.220$ amperes.

$W_{0}=25.3$ watts.

$L_{0}=243$ lumens.

$l_{0}=9.61$ lumens per watt.

Enter table 2 (column 2) at 9.61 lumens per watt to determine the per cent of normal voltage at this efficiency. From column 1 of the line containing 9.61 lumens per watt we find that the lamp operates at 98 per cent of normal volts. 
Since 115 volts is then 98 per cent of normal volts, 124 volts is $(124 / 115) \times 98=$ 105.7 per cent of normal volts. The line of the table, interpolated (column 1 ) containing 105.7 per cent of normal volts contains also the lumens per watt and percentages of normal lumens, amperes, and watts of the lamp at 124 volts. By multiplying the known values of lumens, amperes, and watts at 115 volts by the ratios of the percentage values read from lines corresponding to 105.7 per cent and 98 per cent of Table 2 , values at 124 volts are obtained,

The tabular statement below contains the complete calculations:

\begin{tabular}{|c|c|c|c|c|}
\hline$t$ & $\begin{array}{c}\text { Values read } \\
\text { directly } \\
\text { from table } \\
2,9.61 \text { lu- } \\
\text { mens per } \\
\text { watt cor- } \\
\text { responding } \\
\text { - to } 98 \text { per } \\
\text { cent volts }\end{array}$ & $\begin{array}{c}\text { Values in- } \\
\text { terpolated } \\
\text { into table } \\
2 \text {, at } 105.7 \\
\text { per cent } \\
\text { volts }\end{array}$ & $\begin{array}{l}\text { Computation } \\
\text { to } 124 \text { volts } \\
\text { from columns } \\
2 \text { and } 3\end{array}$ & $\begin{array}{l}\text { Computed values at } \\
124 \text { volts }\end{array}$ \\
\hline 1 & 2 & 3 & 4 & 5 \\
\hline Lumens per watt.... & 9. 61 & 11.12 & & 11.12 lumens per watt. \\
\hline Lumens..... & $\begin{array}{r}\text { Per cent } \\
93.1\end{array}$ & $\begin{array}{r}\text { Per cent } \\
121.3\end{array}$ & $243 \times 121.3$ & 317 lumens. \\
\hline Amperes . - . & 98.8 & 103. 25 & $\begin{array}{c}93.1 \\
0.220 \times 103.25 \\
08.8\end{array}$ & 0.230 amperes. \\
\hline Watts_- & 96.8 & 109.1 & $\frac{25.3 \times 109.1}{96.8}$ & \\
\hline
\end{tabular}

Note.-Column 5 gives the required values.

Example 2.-A 100-watt, gas-filled tungsten-filannent lamp is measured at 125 volts and the following values are obtained:

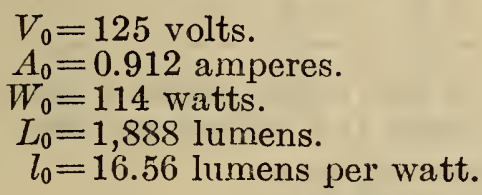

Find amperes, watts, lumens, and lumens per watt at 100 volts. Table 4 , page 728 is applicable in this example. Enter Table 4 to find in column 2, 16.56 lumens per watt. It is not found, but by interpolation between 16.49 and 16.76 we have for 16.56 lumens per watt, the following values:
Per cent normal volts $=115.26=V_{t}$.
Per cent normal lumens $=164.6=L_{t}$.
Per cent normal amperes $=107.7=A_{t}$.
Per cent normal watts $=124.2=W_{t}$.
Lumens per watt $\quad=16.56=l_{t}$.

Then

$$
V^{\prime}{ }_{t}=V_{1} / V_{0} \times V_{t}=100 / 125 \times 115.26=92.2
$$

Enter table 4 at 92.2 per cent volts, interpolate and compute by using the ratios from lines 115.26 and 92.2 per cent normal volts in the table. We obtain then:

$$
\begin{aligned}
& \text { Lumens }=1,888 \times \frac{74.2}{164.6}=851 . \\
& \text { Amperes }=0.912 \times \frac{95.9}{107.7}=0.812 . \\
& \text { Watts }=114 \times \frac{88.4}{124.2}=81.1 .
\end{aligned}
$$

Lumens per watt $=10.49$. 


\section{CHARACTERISTICS OF GAS-FILLED TUNGSTEN LAMPS}

TABLE 3.-Characteristics of gas-filled lamps, 40 to 50 watts (also 3-candlepower, 6 to 8 volt lamps). Normal efficiency, 12.5 lumens per watt

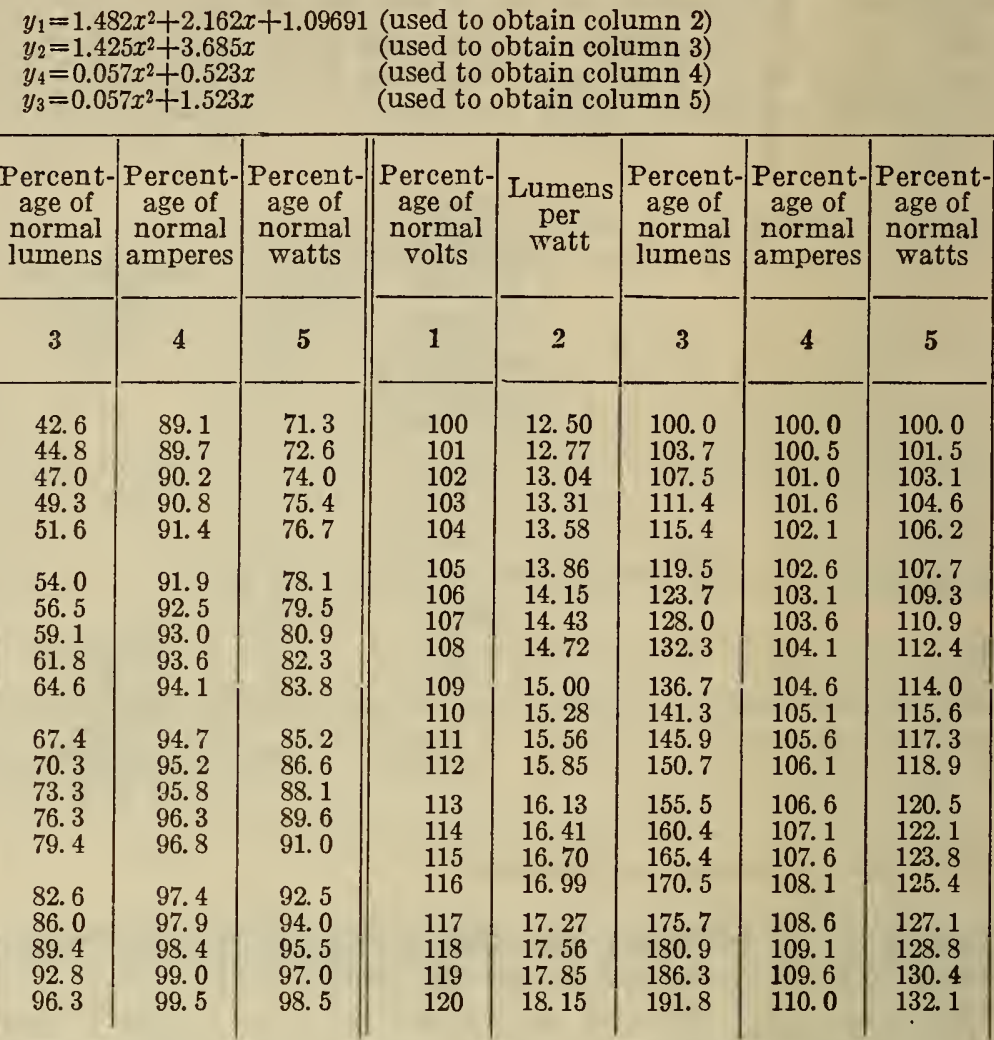

TABLE 4.-Characteristics of gas-filled lamps, 60 to 150 watts, inclusive (also 21candlepower 6 to 8 volt lamps). Normal efficiency, 12.5 lumens per watt $\begin{array}{ll}y_{1}=-1.726 x^{2}+2.090 x+1.09691 & \text { (used to obtain column 2) } \\ y_{2}=-1.669 x^{2}+3.613 x & \text { (used to obtain column 3) } \\ y_{4}=0.057 x^{2}+0.523 x & \text { (used to obtain column 4) } \\ y_{3}=0.057 x^{2}+1.523 x & \text { (used to obtain column 5) }\end{array}$

\begin{tabular}{|c|c|c|c|c|c|c|c|c|c|}
\hline $\begin{array}{c}\text { Percent- } \\
\text { age of } \\
\text { normal } \\
\text { volts }\end{array}$ & $\begin{array}{c}\text { Lumens } \\
\text { per } \\
\text { watt }\end{array}$ & $\begin{array}{c}\text { Percent- } \\
\text { age ot } \\
\text { normal } \\
\text { lumens }\end{array}$ & $\begin{array}{c}\text { Percent } \\
\text { age of } \\
\text { normal } \\
\text { amperes }\end{array}$ & $\begin{array}{c}\text { Percent- } \\
\text { age of } \\
\text { normal } \\
\text { watts }\end{array}$ & $\begin{array}{c}\text { Percent } \\
\text { age of } \\
\text { normal } \\
\text { volts }\end{array}$ & $\begin{array}{c}\text { Lumens } \\
\text { per } \\
\text { watt }\end{array}$ & $\begin{array}{c}\text { Percent } \\
\text { age of } \\
\text { normal } \\
\text { lumens }\end{array}$ & $\begin{array}{l}\text { Percent- } \\
\text { age of } \\
\text { normal } \\
\text { amperes }\end{array}$ & $\begin{array}{c}\text { Percent- } \\
\text { age of } \\
\text { normal } \\
\text { watts }\end{array}$ \\
\hline 1 & 2 & 3 & 4 & 5 & 1 & 2 & 3 & 4 & 5 \\
\hline $\begin{array}{l}80 \\
81 \\
82 \\
83 \\
84\end{array}$ & $\begin{array}{l}7.55 \\
7.79 \\
8.02 \\
8.26 \\
8.49\end{array}$ & $\begin{array}{l}43.1 \\
45.2 \\
47.4 \\
49.7 \\
52.1\end{array}$ & $\begin{array}{l}89.1 \\
89.7 \\
90.2 \\
90.8 \\
91.4\end{array}$ & $\begin{array}{l}71.3 \\
72.6 \\
74.0 \\
75.4 \\
76.7\end{array}$ & $\begin{array}{l}100 \\
101 \\
102 \\
103 \\
104\end{array}$ & $\begin{array}{l}12.50 \\
12.76 \\
13.02 \\
13.29 \\
13.55\end{array}$ & $\begin{array}{l}100.0 \\
103.6 \\
107.4 \\
111.2 \\
115.1\end{array}$ & $\begin{array}{r}100.0 \\
100.5 \\
101.0 \\
.101 .6 \\
102.1\end{array}$ & $\begin{array}{l}100.0 \\
101.5 \\
103.1 \\
104.6 \\
106.2\end{array}$ \\
\hline $\begin{array}{l}85 \\
86 \\
87 \\
88 \\
89\end{array}$ & $\begin{array}{l}8.73 \\
8.96 \\
9.21 \\
9.45 \\
9.70\end{array}$ & $\begin{array}{l}54.5 \\
57.0 \\
59.6 \\
62.3 \\
65.0\end{array}$ & $\begin{array}{l}91.9 \\
92.5 \\
93.0 \\
93.6 \\
94.1\end{array}$ & $\begin{array}{l}78.1 \\
79.5 \\
80.9 \\
82.3 \\
83.8\end{array}$ & $\begin{array}{l}105 \\
106 \\
107 \\
108\end{array}$ & $\begin{array}{l}13.82 \\
14.08 \\
14.34 \\
14.61\end{array}$ & $\begin{array}{l}119.1 \\
123.1 \\
127.3 \\
131.5\end{array}$ & $\begin{array}{l}102.6 \\
103.1 \\
103.6 \\
104.1\end{array}$ & $\begin{array}{l}107.7 \\
109.3 \\
110.9 \\
112.4\end{array}$ \\
\hline $\begin{array}{l}90 \\
91 \\
92 \\
93 \\
94\end{array}$ & $\begin{array}{r}9.95 \\
10.20 \\
10.44 \\
10.70 \\
10.95\end{array}$ & $\begin{array}{l}67.8 \\
70.7 \\
73.6 \\
76.6 \\
79.7\end{array}$ & $\begin{array}{l}94.7 \\
95.2 \\
95.8 \\
96.3 \\
96.8\end{array}$ & $\begin{array}{l}85.2 \\
86.6 \\
88.1 \\
89.6 \\
91.0\end{array}$ & $\begin{array}{l}109 \\
110 \\
111 \\
112\end{array}$ & $\begin{array}{l}14.88 \\
15.15 \\
15.42 \\
15.69\end{array}$ & $\begin{array}{l}135.8 \\
140.2 \\
144.7 \\
149.2\end{array}$ & $\begin{array}{l}104.6 \\
105.1 \\
105.6 \\
106.1\end{array}$ & $\begin{array}{l}114.0 \\
115.6 \\
117.3 \\
118.9\end{array}$ \\
\hline $\begin{array}{l}95 \\
96 \\
97 \\
98 \\
99\end{array}$ & $\begin{array}{l}11.21 \\
11.46 \\
11.72 \\
11.98 \\
12.24\end{array}$ & $\begin{array}{l}82.9 \\
86.2 \\
89.5 \\
92.9 \\
96.4\end{array}$ & $\begin{array}{l}97.4 \\
97.9 \\
88.4 \\
99.0 \\
99.5\end{array}$ & $\begin{array}{l}92.5 \\
94.0 \\
95.5 \\
97.0 \\
98.5\end{array}$ & $\begin{array}{l}114 \\
115 \\
116 \\
117 \\
118 \\
119 \\
120\end{array}$ & $\begin{array}{l}16.22 \\
16.49 \\
16.76 \\
17.04 \\
17.31 \\
17.58 \\
17.84\end{array}$ & $\begin{array}{l}158.6 \\
163.4 \\
168.2 \\
173.2 \\
178.3 \\
183.4 \\
188.6\end{array}$ & $\begin{array}{l}107.1 \\
107.6 \\
108.1 \\
108.6 \\
109.1 \\
109.6 \\
110.1\end{array}$ & $\begin{array}{l}122.1 \\
123.8 \\
125.4 \\
127.1 \\
128.8 \\
130.4 \\
132.1\end{array}$ \\
\hline
\end{tabular}


TABLE 5.-Characteristics of gas-filled lamps, 200 to 500 watts (also 32-candlepower, 6 to 8 volt, lamps). Normal efficiency, 16.0 lumens per watt

$\begin{array}{ll}y_{1}=-1.690 x^{2}+1.841 x+1.20412 & \text { (used to obtain column 2) } \\ y_{2}=-1.607 x^{2}+3.384 x & \text { (used to obtain column 3) } \\ y_{4}=0.083 x^{2}+0.543 x & \text { (used to obtain column 4) } \\ y_{3}=0.083 x^{2}+1.543 x & \text { (used to obtain column 5) }\end{array}$

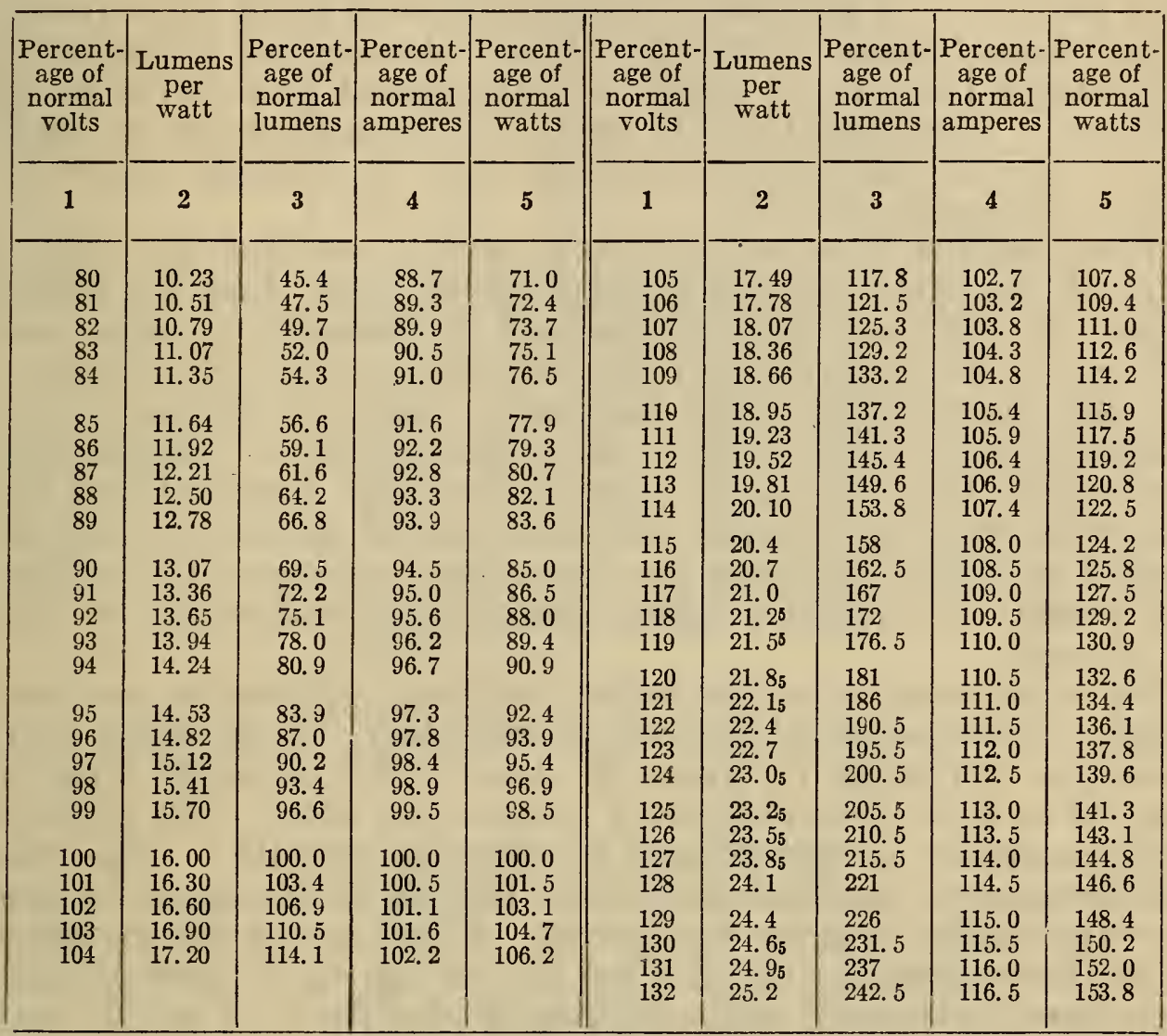

\section{VERIFICATION OF THE CHARACTERISTICS}

The upper range of efficiencies of 500-watt lamps was investigated several years ago in connection with tests made for the optical division of the Bureau of Standards. Starting with a basic value of 17.6 lumens per watt at 105 volts, the following comparison of observed and computed values is an example of the results obtained.

TABLE 6.-Efficiency of 500-watt lamps

\begin{tabular}{|c|c|c|}
\hline \multirow{2}{*}{ Volts } & \multicolumn{2}{|c|}{$\begin{array}{l}\text { Efficiency in lu- } \\
\text { mens per watt }\end{array}$} \\
\hline & Observed & $\begin{array}{l}\text { Com- } \\
\text { puted }\end{array}$ \\
\hline $\begin{array}{r}90 \\
100\end{array}$ & $\begin{array}{l}13.2 \\
16.1\end{array}$ & $\begin{array}{l}13.2 \\
16.1\end{array}$ \\
\hline 105 & 17.6 & \\
\hline 110 & 19.1 & 19.1 \\
\hline 120 & 21.9 & 22.0 \\
\hline 125 & 23.6 & 23.4 \\
\hline 135 & 26.3 & 26.2 \\
\hline
\end{tabular}


Values were recorded for 5-volt steps upward to burn out, which occurred within the step from 195 to 200 volts. Departures from computed values were not very extreme even at the higher points; for example, the observed value at 175 volts was 2.5 per cent below the computed value, and at 185 volts the corresponding difference was 2 per cent. A prohibitive amount of work would be required to assign characteristic values to these extreme points, where the observations have to be taken rapidly against great odds of color difference. Consequently, no attempt has been made to include them in the derivation of equations, and the lumens per watt in Table 5 terminate at 25.2 .

Extrapolations have been made to points considerably below the limits of the tables for gas-filled lamps in work done on 500-watt lamps. In this work the voltage and light output at color match with and in terms of vacuum tungsten lamps were determined. At this color the 500 -watt lamps operated at about 6.7 lumens per watt. Determinations of light output were then made at voltages corresponding to 16.5 lumens per watt in terms of gas-filled standards. Computed from the voltage and light output for color match with vacuum tungsten standards to these upper voltages, the values of light output checked the values obtained by observation to within 0.3 per cent.

The entire range of all the tables has been explored by means of a physical photometer (phototube photometer). A gas-filled cæsium phototube, corrected for color by means of a suitable filter, and attached to a 60 -inch integrating sphere, was used. The phototube circuit is similar to that devised by Sharp and Smith. ${ }^{4}$ This phototube photometer has been used at the Bureau of Standards for over a year in the rating of lamps for life test. Every month the characteristics of the photometer are checked by reading on it three of each of seven sizes of standard lamps ranging in size from 15 to 100 watts. The color temperature range of the light from these lamps is approximately $2,400^{\circ}$ to $2,800^{\circ} \mathrm{K}$. Each time there has been a remarkably close check between the readings thus obtained and the values assigned to the lamps by visual photometry using an 88-inch integrating sphere and Lummer-Brodhun photometer head. There have been other checks on the phototube photometer from time to time and these have shown the photometer to be accurate over a large range of color temperature and flux (lumen output).

All regular sizes of lamps from 15 to 500 watts, and also miniature lamps of 3,21 , and 32 candlepower have been photometered at various voltages to cover the range of the tables of this paper. These lamps were selected at random from the lamps received for life test from five different lamp manufacturers. Typical sets of results are given in Table 7.

4 Sharp and Smith, Trans. Ill. Eng. Soc., vol. 23, p. 434, 1928. 
TABLE 7.-Observed and computed values of lumens and amperes on lamps of various sizes

(a) AVERAGE OF TWO 15-WATT, VACUUM LAMPS (TABLE 2 USED

TO OBTAIN COMPUTED VALUES)

\begin{tabular}{|r|c|c|c|c|}
\hline \multirow{2}{*}{ Volts } & \multicolumn{2}{|c|}{ Lumens } & \multicolumn{2}{c|}{ Amperes } \\
\cline { 2 - 6 } & $\begin{array}{c}\text { Photo- } \\
\text { tube }\end{array}$ & $\begin{array}{c}\text { Com- } \\
\text { puted }\end{array}$ & $\begin{array}{c}\text { Potenti- } \\
\text { ometer }\end{array}$ & $\begin{array}{c}\text { Com- } \\
\text { puted }\end{array}$ \\
\hline 80 & 34.7 & 34.2 & 0.106 & 0.107 \\
90 & 54 & 54 & .114 & .114 \\
100 & 79 & 80 & .122 & .122 \\
115 & 132 & - & 136 &.--- \\
125 & 176 & 176 & .139 & .139 \\
130 & 202 & 204 & .142 & .142 \\
\hline
\end{tabular}

(b) AVERAGE OF TWO 40-WATT GASFILLED LAMPS (TABLE 3 USED TO OBTAIN COMPUTED VALUES)

\begin{tabular}{|l|r|r|r|r|}
\hline 100 & 252 & 254 & 0.332 & 0.330 \\
110 & 366 & 366 & .346 & .346 \\
120 & 508 & 510 & .364 & .362 \\
125 & 592 &.--38 & .370 &. .384 \\
135 & 784 & 784 & .384 & .385 \\
145 & 1,005 & 1,008 & .400 & .400 \\
\hline
\end{tabular}

(c) AVERAGE OF TWO 3-CANDLEPOWER GAS - FILLED LAMPS PUTED VALUES)

\begin{tabular}{|l|r|r|r|r|}
\hline 6.725 & 34.2 &..---- & 0.500 &..$--1 .-$ \\
7.50 & 51.2 & 51.4 & .527 & 0.528 \\
8.00 & 64.7 & 64.8 & .544 & .547 \\
8.5 & 79.8 & 80.6 & .560 & .564 \\
\hline
\end{tabular}

(d) AVERAGE OF TWO 100-WATT, GAS-FILLED LAMPS (TABLE USED TO OBTAIN COMPUTED VALUES)

\begin{tabular}{|r|r|c|c|c|}
\hline 90 & 572 & 570 & 0.766 & 0.767 \\
100 & 852 & 852 & .810 & .811 \\
115 & 1,411 & -872 &..-- \\
125 & 1,888 & 1,888 & .912 & .911 \\
130 & 2,158 & 2,150 & .931 & .931 \\
\hline
\end{tabular}

(e) AVERAGE OF TWO 21-CANDLEPOWER GAS - FILLED LAMPS (TABLE 4 USED TO OBTAIN COMPUTED VALUES)

\begin{tabular}{|l|l|l|l|l|}
\hline 5.00 & 110 & 109 & 2.15 & 2.15 \\
5.50 & 156 & 155 & 2.26 & 2.26 \\
6.00 & 211 & 211 & 2.36 & 2.36 \\
6.35 & 256 & $-\cdots-.-$ & 2.44 &...- \\
\hline
\end{tabular}

(1) AVERAGE OF TWO 200-WATT, GAS. FILLED LAMPS (TABLE 5 USED TO OBTAIN COMPUTED VALUES)

\begin{tabular}{|r|c|c|c|c|}
\hline 90 & 1,208 & 1,216 & 1.425 & 1.424 \\
100 & 1,778 & 1,786 & 1.507 & 1.507 \\
115 & 2,912 & $-3 .-$ & 1.624 & $-1 .--$ \\
125 & 3,868 & 3,847 & 1.699 & 1.700 \\
129 & 4,299 & 4,285 & 1.728 & 1.730 \\
\hline
\end{tabular}

(g) AVERAGE OF TWO 32-CANDLEPOWER, GAS-FILLED LAMPS (TABLE 5 USED TO OBTAIN COMPUTED VALUES)

\begin{tabular}{|c|c|c|c|c|}
\hline $\begin{array}{l}4.00 \\
4.50 \\
5.00 \\
5.50 \\
6.023\end{array}$ & $\begin{array}{r}92 \\
142 \\
206 \\
288 \\
390\end{array}$ & $\begin{array}{r}90 \\
141 \\
206 \\
288\end{array}$ & $\begin{array}{l}2.91 \\
3.08 \\
3.25 \\
3.42 \\
3.59\end{array}$ & $\begin{array}{l}2.89 \\
3.08 \\
3.24 \\
\text { 3. } 42\end{array}$ \\
\hline
\end{tabular}




\section{CONCLUSION AND ACKNOWLEDGMENTS}

The equations and tables embodied in this paper have been used for several years at the Bureau of Standards in connection with the routine testing of incandescent lamps. For the various sizes of lamps, slide rules have been devised and these are used to determine the voltages at which lamps are to be burned in order to operate at any desired efficiency, or the operating efficiency of the lamps when burned at any designated voltage. Although this is the general use of the equations and tables here, they have found other occasional uses, such as for determining the voltages at which to calibrate lamps when a designated lumen output or efficiency of the lamps is required. The results obtained by these computations have been checked many times on a visual photometer by groups of experienced observers.

The authors desire to acknowledge the work of the late J. F. Skogland in connection with this paper. He had much of the data here presented nearly ready for publication when he died. It was felt, however, that the equations should be further checked before publication, and this has been done. We wish to state also that the data from which the 200 to 500 watt lamp equations were derived were obtained by cooperative work between the Nela Park laboratories of the General Electric Co. and the Bureau of Standards.

Washington, August 16, 1932. 